\title{
Systematic prey preference by introduced mice exhausts the ecosystem on Antipodes Island
}

\author{
James C. Russell (i) · Joanne E. Peace • Melissa J. Houghton • Sarah J. Bury • \\ Thomas W. Bodey
}

Received: 5 August 2018/Accepted: 10 December 2019/Published online: 14 January 2020

(C) The Author(s) 2020

\begin{abstract}
House mice (Mus musculus) are a widespread invasive species on islands. Where they are the sole introduced mammal they can have particularly strong negative impacts on recipient ecosystems. House mice impacts have been documented on almost every component of the terrestrial ecosystem on Southern Ocean islands, including plants, invertebrates, birds and ecosystem function. We undertook a comprehensive study to determine the impacts of house mice on Antipodes Island, New Zealand. This study was done prior to mouse eradication to inform monitoring and restoration. We used invertebrate pitfall trapping on the main Antipodes Island and
\end{abstract}

J. C. Russell $(\bowtie)$ · J. E. Peace · T. W. Bodey $(\square)$

School of Biological Sciences, University of Auckland,

Auckland 1142, New Zealand

e-mail: j.russell@auckland.ac.nz

T. W. Bodey

e-mail: t.w.bodey@exeter.ac.uk

M. J. Houghton

Centre for Biodiversity and Conservation Science, School of Biological Sciences, The University of Queensland,

St. Lucia, QLD 4072, Australia

S. J. Bury

National Institute of Water and Atmospheric Research Ltd., Greta Point, Hataitai, Wellington 6021, New

Zealand

T. W. Bodey

Environment and Sustainability Institute, University of

Exeter, Penryn TR10 9FE, UK neighbouring mouse-free offshore islands together with mouse stomach contents and stable isotope analyses of mouse livers to examine dietary preferences. We identified directly impacted and consumed invertebrate Orders relative to their abundance and provided a comprehensive picture of resource flow and overlap in the invaded terrestrial ecosystem. The remote terrestrial ecosystem of Antipodes Island was tightly circumscribed with strong resource overlap. Mouse diet varied seasonally with resource availability, dominated by invertebrates and land birds in summer, and plants and seabirds in winter. Invertebrates that were preferentially preyed upon were Amphipoda, Lepidoptera and some species of Coleoptera. These patterns suggest the ecosystem is annually driven by a seasonal bottom-up resource pulse over summer, where mice are a selective predator, differentially preying on invertebrates relative to invertebrate abundance. Mice appear to be exhausting preferred prey as they systematically consume their way through the terrestrial ecosystem. Land bird diet also varied seasonally and some of these birds likely competed with mice for invertebrate prey. Eradication of mice from Antipodes Island should reduce the predation on invertebrates and reduce the effects of competition and predation on land birds. This should have flow-on effects to the abundance of invertebrates and endemic land bird sub-species of pipit and snipe. 
Keywords Diet - House mouse - Mus musculus . Southern Ocean · Invertebrates - Stable isotopes · Stomach content

\section{Introduction}

House mice (Mus musculus) are a widespread invasive species and one of the most commonly introduced rodent species to islands (Moors and Atkinson 1984; Angel et al. 2009). They are hardy and adaptive with plastic dietary requirements allowing them to successfully adapt to and establish themselves in a variety of habitats (e.g. Renaud et al. 2015). Ecosystems invaded by mice suffer various impacts, from seed predation to attack of seabirds (Angel et al. 2009; St Clair 2011; Bolton et al. 2014; Cuthbert et al. 2016), to altered ecosystem function (Eriksson and Eldridge 2014). On subantarctic islands, mice consume most of the food items available (Le Roux et al. 2002). However, invertebrates are a favoured prey item, and mice can contribute to their decline and even extinction (Rowe-Rowe et al. 1989; Le Roux et al. 2002; Smith et al. 2002). Through their predation of invertebrates, mice may also compete with insectivorous birds and impact on ecosystem function and trophic links (Huyser et al. 2000; Marris 2000; Le Roux et al. 2002; Miskelly et al. 2006).

The Antipodes Islands in the New Zealand subantarctic region are remote, but mice have been present as the sole invasive mammal since the early 1900s. Given their unique genetics in New Zealand, the founders are likely to have been from the shipwreck of the President Felix Faure (Veale et al. 2018). Since colonisation, they have spread across the entire main Antipodes Island, but have never been detected on nearby islands and rock stacks (Russell 2012). They were found to be "abundant at all altitudes" in 1969 (Warham and Johns 1975), but Marris (2000) noted that mouse abundance decreased with increasing altitude. Density of mice on Antipodes Island was estimated at around 50-100/ha (Russell 2012; Elliot et al. 2015). Due to the unique ecosystem and isolation of Antipodes Island, the impacts of mice are concerning, particularly as endemic birds, invertebrates and plants might constitute major prey items (Moors and Atkinson 1984; Godley 1989; Patrick 1994).
The Antipodes Islands exhibit high levels of invertebrate endemism (Marris 2000). There are 23 native Coleoptera species with nine island endemics (Marris 2000) and 19 Lepidoptera species with four island endemics (Patrick 1994). The main Antipodes Island lacks medium-sized flightless invertebrates, and mice have been invoked as the reason (Patrick 1994). For example, an undescribed weta species (Orthoptera) is known from mouse-free offshore Bollons Island, but has not been collected from the main Antipodes Island (Marris 2000; McIntosh 2001). Investigations by Marris (2000) and Russell (2012) inferred that mice impacted on the abundance, composition, and distribution of the invertebrate fauna on Antipodes Island, but these investigations did not directly study mouse diet.

In this study, we initiated investigations to further clarify the impacts of mice on the main Antipodes Island, prior to their eradication in winter 2016 (Horn et al. 2018). We combined invertebrate pitfall trapping with stomach contents and stable isotope analyses to determine: (1) what are the major resources for mice on Antipodes Island? (2) which invertebrates have been most impacted by mice compared to uninvaded offshore islands? and (3) which invertebrates are preferentially targeted as prey? Together this allowed us to make predictions about anticipated species recoveries following mouse eradication. This work was undertaken over the course of three field trips: summer (January) 2011, winter (July) 2013, and autumn and winter (April to July) 2016.

\section{Methods}

Study site

The Antipodes Islands (2097 ha; $49^{\circ} 41^{\prime} \mathrm{S} ; 178^{\circ} 48^{\prime} \mathrm{E}$ ) lie $872 \mathrm{~km}$ south-east of New Zealand (Fig. 1). The climate is characterised by strong south-westerly winds with frequent cloud, fog and rain, and cool temperatures $\left(2-13{ }^{\circ} \mathrm{C}\right)$ with little seasonal variation (Taylor 2006). The island group is an important and diverse breeding site for seabirds, and two species of endemic parakeets (Cyanoramphus spp.). Vegetation on the main Antipodes Island (2025 ha) is entirely composed of tussock grassland (Poa and Carex spp.) interspersed with some shrubs (Coprosma spp.) and ferns (see Godley 1989 for a complete description). 


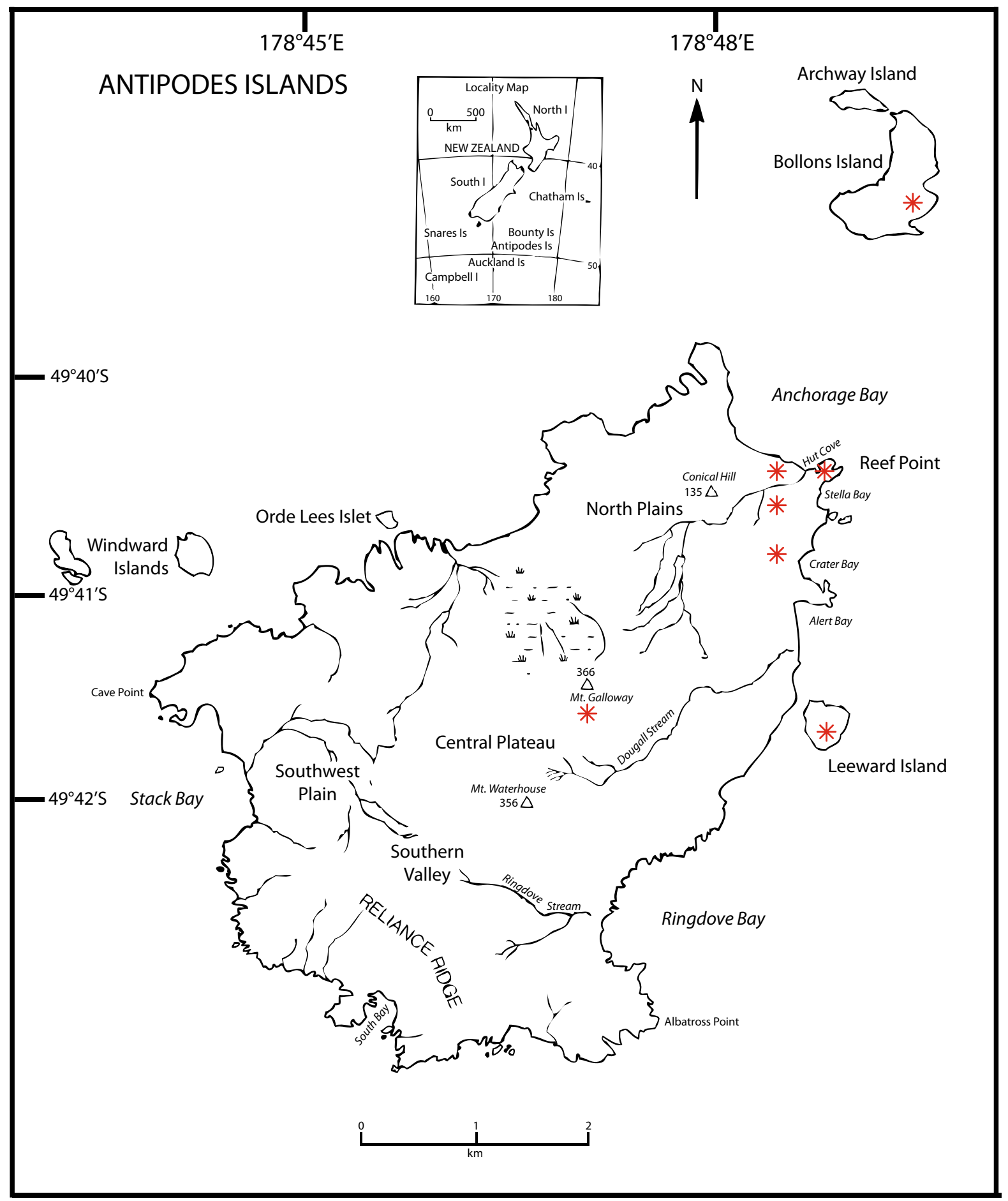

Fig. 1 Antipodes Islands. Sampling sites are indicated by asterisks

Five study sites were focused upon. At the north-east end of the island Anchorage Bay, Hut Creek and Reef Point sites are neighbouring low altitude coastal locations with dense tussock vegetation reaching $2 \mathrm{~m}$ in height; whereas the more distant higher altitude North Plains plateau site supports lower vegetation of 
$0.5 \mathrm{~m}$ height made up of separated cushion plants (Russell 2012). The fifth study site was the summit of the highest point on the island, Mt Galloway.

\section{Pitfall trapping}

Surface invertebrates were pitfall trapped at Anchorage Bay, Reef Point, Hut Creek, the North Plains and the summit of Mt Galloway in summer (January) 2011, winter (July) 2013 and winter (June) 2016 and on the mouse-free offshore islands of Bollons and Leeward in winter (July) 2016. At each site, ten pitfall traps ( $80 \mathrm{~mm}$ diameter, $90 \mathrm{~mm}$ depth) were spaced $10 \mathrm{~m}$ apart. Traps were buried with their rim flush with the surface of the ground. They were then covered with a green plastic lid and filled to approximately $2 \mathrm{~cm}$ depth with a 50/50 mix of glycol and water plus a drop of detergent. After at least 10 days (exactly in 2011 and 2013, but variable in 2016), the trap contents were removed and subsequently identified to Class or Order, except for Coleoptera (beetles), which were identified to species. These data were used to determine baseline impacts of the presence of mice on invertebrate relative abundance, by comparing relative abundance on the mouse-invaded main Antipodes Island with mouse-free offshore islands of Bollons and Leeward in winter 2016. The effects of site, nested within mouse status, on invertebrate communities were tested using permutation multivariate analyses of variance with 999 permutations, and visualised with non-metric multidimensional scaling using Euclidean distance. Euclidean distance was used instead of a species similarity measure because the islands share the same pool of invertebrate species and the focus was on changes in their abundance and distribution.

\section{Stomach contents}

Twenty mice were captured using Victor snap-traps baited with peanut butter placed at Anchorage Bay, Reef Point and the North Plains in summer (January) 2011 and at Hut Creek in autumn (April) 2016. The contents of mouse stomachs were individually sieved $\left(1 \mathrm{~mm}^{2}\right)$ under running water and emptied into Petri dishes for examination. All stomachs examined were over one quarter full and so should not over-represent hard parts of prey as per Le Roux et al. (2002). Stomach contents were quantified in two ways. The volume of invertebrate and vertebrate remains, vegetation, and unknown material were estimated visually under a binocular microscope. Then the invertebrate portion was examined under a binocular microscope to determine the minimum number of representatives of each Order as calculated from identifiable remains. Identification was made through reference to invertebrate collections held at the University of Auckland and voucher specimens are lodged at the Auckland War Memorial Museum. These data were used to determine mouse preference for different invertebrate Orders as reflected by proportional occurrence in their diet relative to proportional abundance in pitfall traps on Antipodes Island in summer 2011 and winter 2016.

\section{Stable isotopes}

Samples for stable isotope analysis were collected in summer (January) 2011 and winter (July) 2013 at Anchorage Bay, Reef Point and North Plains, except for land and seabird samples, which were collected at large across the island. Mice were live-captured in Longworth traps baited with peanut butter, euthanised, and liver samples were taken during autopsy. Land birds were captured in nets and seabirds by hand, and all were bled from the metatarsal vein. Land invertebrates were pitfall trapped or litter sorted and identified to Order. These samples were collected in association with other population biology (see Russell 2012) and non-target impact assessment work being undertaken on Antipodes Island in preparation for mouse eradication. Marine invertebrates, land plants and marine macroalgae were all hand-collected. All tissue samples were stored at room temperature in the same batch of $70 \%$ ethanol, with the exception of feathers that were stored dry and loose in bags. These samples were used to determine mouse preference for resources other than invertebrates on Antipodes Island.

Samples (excluding blood) were cleaned, dried, ground and weighed to the nearest microgram. Softbody tissue was first removed from hard-shelled organisms (snails and limpets). Lipids were not extracted from animal specimens, but $\delta^{13} \mathrm{C}$ values were corrected following equations in Fry (2002). Stable isotope analyses were carried out on a DELTA $\mathrm{V}$ Plus continuous flow isotope ratio mass spectrometer linked to a Flash 2000 elemental analyser using a MAS 200 R autosampler (ThermoFisher Scientific, 
Bremen, Germany) at the NIWA Environmental Stable Isotope Facility in Wellington, New Zealand. Using ISODAT (Thermo Fisher Scientific) software, $\delta^{15} \mathrm{~N}$ values were calibrated against a $\mathrm{N}_{2}$ reference gas. Carbon isotope values were calibrated against a $\mathrm{CO}_{2}$ reference gas, relative to the international standard Carrara Marble NSB-19 (National Institute of Standards and Technology (NIST), Gaithersberg, MD, USA). NSB-19, was calibrated against the original Pee Dee Belemnite (PDB) limestone standard and was then corrected for ${ }^{17} \mathrm{O}$. Sample $\delta^{15} \mathrm{~N}$ values were twopoint normalised using isotopic data from the daily analysis of National Institute of Standards and Technology (NIST) 8573 USGS40 L-glutamic acid and NIST 8548 IAEA-N2 Ammonium sulphate. Sample $\delta^{13} \mathrm{C}$ values were two-point normalised using isotopic data from the daily analysis of NIST 8573 USGS40 Lglutamic acid and NIST 8542 IAEA-CH-6 Sucrose. Estimates of precision were obtained from repeat analysis of the working laboratory standard DLLeucine (DL-2-Amino-4-methylpentanoic acid, C6H13NO2, Lot 127H1084, Sigma, Australia) which gave a precision better than $0.15 \%$ ( $1 \mathrm{SD}$ ) for both carbon and nitrogen. Data from the daily analysis of USGS65 Glycine were used to check accuracy, with both carbon and nitrogen accurate to within $0.2 \%$ over the analysis period of a year.

Univariate analyses of variances were used to identify significant differences in stable isotope values among taxonomic groups and years (as a proxy for seasons). The contribution of each potential source to mouse diet, considered separately by year, was then determined using Bayesian mixing models implemented in the R package SIMMR (Parnell et al. 2013). Trophic discrimination factors for mouse livers were obtained through taking the mean and standard deviation from the values reported from studies on this specific tissue in the literature (DeNiro and Epstein 1978, 1981; Arneson and MacAvoy 2005). Although obtaining trophic discrimination factors from controlled feeding studies would be optimal, in this case it was not logistically practical. Samples were only compared within a year, where all samples were preserved in the same ethanol batch. Such storage was necessary given the remote location of the study site. While there is debate within the literature, this storage method has been shown to have minimal effect on stable isotope ratios of nitrogen or carbon in relevant taxa including invertebrates, birds and mammals
(Barrow et al. 2008; Bugoni et al. 2008; Kiszka et al. 2014; Hogsden and McHugh 2017). Regardless, the use of the same solvent for all samples from these within-year analyses will further reduce any errors of interpretation that may be associated with its use. Similarly, although samples were obtained from different tissue types for different taxa, differential fractionation was also assumed to have minimal effect on stable isotope values, so no correction factor was applied during the modelling analysis. All analyses were undertaken in $\mathrm{R}$ 3.4.3.

\section{Results}

Pitfall trapping

Results from invertebrate pitfall trapping on the main Antipodes Island in summer (January) 2011 and winter (July) 2013 have been described elsewhere (Russell 2012; Elliot et al. 2015). We present the additional pitfall trapping results, collected in association with mouse eradication on the main Antipodes Island, and for the first time, mouse-free offshore islands from winter (June) 2016.

On the main Antipodes Island in winter 2016, similar to winter 2013, most invertebrates collected were Coleoptera $(36 \%)$ followed by Isopoda $(26 \%)$ and Diptera (21\%). Over one-third of the individuals were collected at Anchorage Bay (35\%), where pitfall traps were out for the standard length of 10 nights, followed by North Plains (27\%), Reef Point (20\%) and Hut Creek (10\%) where pitfall traps were out for a longer period of 15 nights. In contrast, on the mousefree offshore islands in winter 2016, where pitfall traps were out for 13 nights, most invertebrates collected were Coleoptera (49\%) followed by Amphipoda (44\%). For all taxa combined more individuals were collected on Bollons Island $(71 \%)$ compared to Leeward Island (29\%).

Differences in invertebrate communities among islands and sites were primarily driven by the presence of mice on the main Antipodes Island $\left(\mathrm{R}^{2}=0.56\right.$, $p<0.001)$ and then among sampling sites on the main Antipodes Island $\left(\mathrm{R}^{2}=0.22, p<0.001\right)$. A nonmetric multidimensional scaling has low stress (0.03) and clearly shows the separation among islands with and without mice, and the greater variation in abundances of invertebrates on the latter (Fig. 2). 


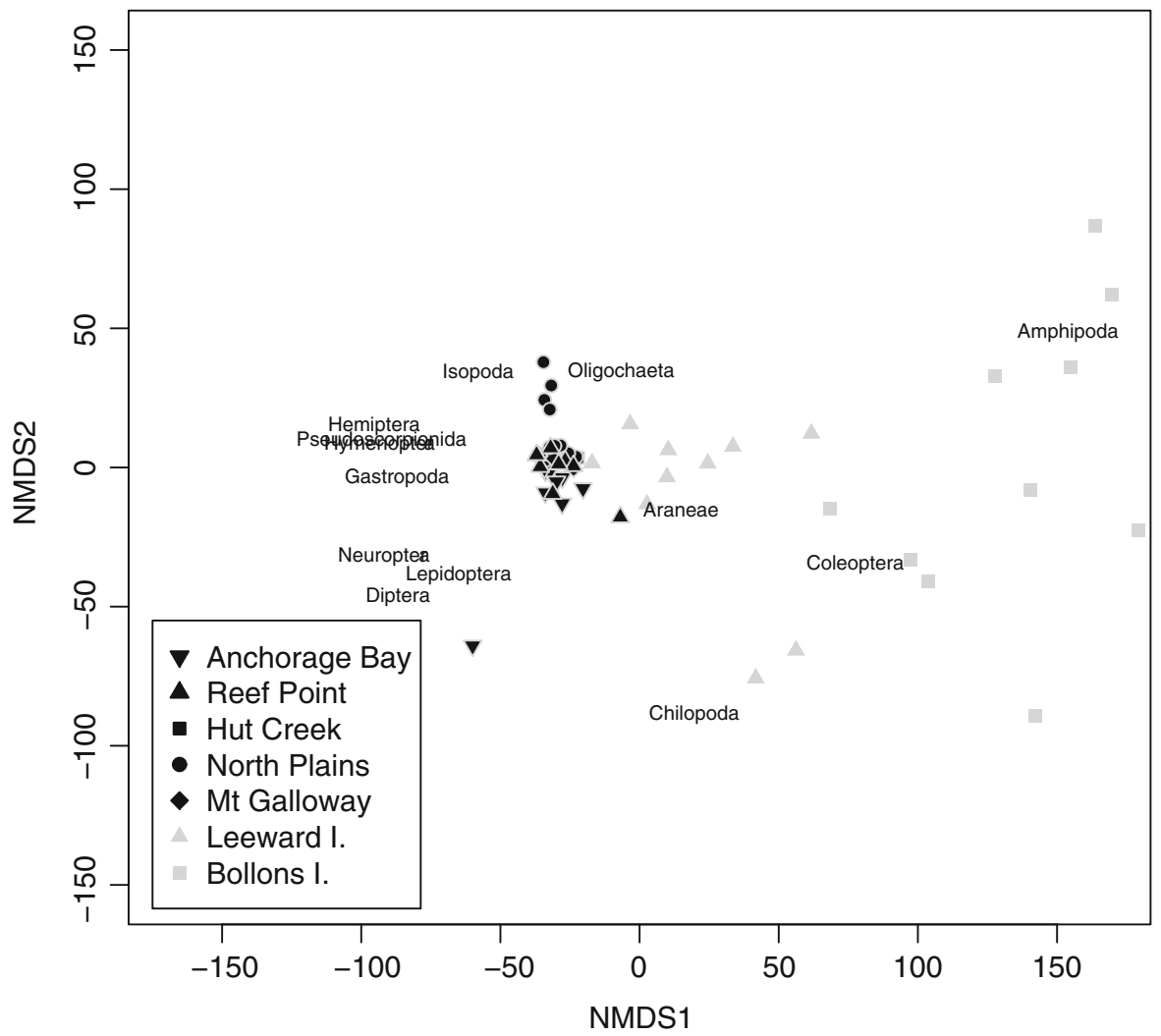

Fig. 2 Non-metric multidimensional scaling (NMDS) bi-plot of invertebrate communities comprising 14 Orders on the mouse-invaded main Antipodes Island (black) and mouse-free

For all taxa combined in 2016, average invertebrate abundance in pitfall traps on mouse-invaded Antipodes Island was $15 \%$ of the invertebrate abundance of pitfall traps on mouse-free offshore islands, even though pitfall traps were out for a shorter time at most of the latter sites. While the number of Orders detected between invaded and uninvaded islands was similar, abundance responses were variable with reductions of $100 \%$ in Amphipoda, 89\% in Chilopoda and Coleoptera and $62 \%$ in Aranae, but increases of $20 \%$ in offshore Leeward and Bollons Islands (grey). Different sampling sites are indicated by symbols as shown in the figure legend. Stress $=0.03$

Lepidoptera, 238\% in Diptera and $873 \%$ in Gastropoda.

\section{Stomach contents}

Mouse stomachs contained invertebrate remains, plant material (leaf, seed and stem fragments), and bird remains (feathers, fat deposits, skin and muscle) (Table 1). All stomachs that had vertebrate remains also contained feathers. The nine mouse stomachs
Table 1 Frequency of occurrence and volume of each dietary component for mice caught on Antipodes Island in summer (January) 2011 and autumn (April) 2016

\begin{tabular}{lllll}
\hline & \multicolumn{2}{l}{ Food category } & & \\
\cline { 2 - 5 } & Invertebrate & Vertebrate & Vegetation & Unknown \\
\hline January 2011 & & & & \\
$\quad \begin{array}{l}\text { Frequency of occurrence }(n=9) \\
\text { Percentage range }\end{array}$ & 9 & $0-5$ & $0-10$ & $0-10$ \\
April 2016 & $90-95$ & & & \\
Frequency of occurrence $(n=11)$ & 9 & 9 & 11 & 9 \\
Percentage range & $0-80$ & $0-75$ & $1-95$ & $0-30$ \\
\hline
\end{tabular}


collected in summer (January) 2011 generally had much higher volumes of invertebrate remains compared to the 11 collected in autumn (April) 2016 (mean \pm SE: $21 \pm 11$ vs. $3 \pm 1$ minimum invertebrate individuals). Higher levels of bird remains and plant material were seen in the autumn compared to summer samples (Table 1).

Overall eight invertebrate Orders were identified in stomachs (Table 2) with the most common components being Diptera larvae (41\% of the identified individuals), Lepidoptera larvae (26\%), Acarina (13\%), adult Coleoptera (8\%) and Araneae (7\%). Diptera larvae and Acarina were only present in two mouse stomachs (M32 and M34) from mice caught at the Anchorage Bay penguin colony (Table 2). The Acarina observed are most likely the species, Ixodes uriae, as noted by Marris (2000). Three individuals of the endemic weevil, Gromilus insularis antipodarum,

Table 2 Minimum number of invertebrates per Order and occurrence of feathers in 20 mouse stomachs from Antipodes Island

\begin{tabular}{|c|c|c|c|c|c|c|c|c|c|c|}
\hline \multirow{2}{*}{$\begin{array}{l}\text { Stomach ID } \\
\text { Location }\end{array}$} & \multicolumn{10}{|c|}{ Minimum number of individuals } \\
\hline & M31 & M32 & M34 & M129 & M130 & M132 & M133 & M134 & M173 & $\begin{array}{l}\text { M801 } \\
\mathrm{HC}\end{array}$ \\
\hline \multirow{2}{*}{\multicolumn{11}{|c|}{ Aves }} \\
\hline & & & & & & & & & & \\
\hline Feathers present & No & Yes & Yes & No & No & Yes & No & Yes & No & No \\
\hline \multicolumn{11}{|l|}{ Arachnida } \\
\hline Acarina & 0 & 22 & 6 & 0 & 0 & 0 & 0 & 0 & 0 & 0 \\
\hline Araneae & 1 & 1 & 1 & 1 & 0 & 1 & 1 & 2 & 1 & 0 \\
\hline \multicolumn{11}{|l|}{ Insecta } \\
\hline Coleoptera (larvae) & 0 & 0 & 0 & 0 & 0 & 0 & 0 & 1 & 0 & 0 \\
\hline Coloeptera (adult) & 1 & 2 & 0 & 2 & 1 & 2 & 1 & 3 & 3 & 0 \\
\hline Diptera (larvae) & 0 & 80 & 9 & 0 & 0 & 0 & 0 & 0 & 0 & 0 \\
\hline Lepidoptera (larvae) & 1 & 0 & 10 & 7 & 1 & 17 & 1 & 5 & 1 & 0 \\
\hline Lepidoptera (adult) & 0 & 0 & 0 & 0 & 0 & 0 & 0 & 0 & 0 & 0 \\
\hline Thysanoptera & 0 & 0 & 0 & 0 & 0 & 0 & 0 & 0 & 0 & 0 \\
\hline Oligochaeta & 0 & 0 & 0 & 1 & 0 & 0 & 0 & 1 & 0 & 0 \\
\hline Pseudoscorpionida & 0 & 0 & 0 & 0 & 0 & 0 & 0 & 0 & 0 & 0 \\
\hline Stomach ID & M803 & M806 & M855 & M857 & M859 & M860 & M861 & M863 & M866 & M880 \\
\hline Location & $\mathrm{HC}$ & $\mathrm{HC}$ & $\mathrm{HC}$ & $\mathrm{HC}$ & $\mathrm{HC}$ & $\mathrm{HC}$ & $\mathrm{HC}$ & $\mathrm{HC}$ & $\mathrm{HC}$ & $\mathrm{HC}$ \\
\hline \multicolumn{11}{|l|}{ Aves } \\
\hline Feathers present & Yes & No & Yes & Yes & Yes & Yes & Yes & Yes & Yes & Yes \\
\hline \multicolumn{11}{|l|}{ Arachnida } \\
\hline Acarina & 0 & 0 & 0 & 0 & 0 & 0 & 0 & 0 & 0 & 0 \\
\hline Araneae & 1 & 1 & 2 & 1 & 0 & 0 & 1 & 1 & 0 & 0 \\
\hline \multicolumn{11}{|l|}{ Insecta } \\
\hline Coleoptera (larvae) & 0 & 1 & 0 & 1 & 0 & 0 & 0 & 0 & 0 & 0 \\
\hline Coloeptera (adult) & 0 & 0 & 1 & 0 & 0 & 0 & 1 & 0 & 0 & 0 \\
\hline Diptera (larvae) & 0 & 0 & 0 & 0 & 0 & 0 & 0 & 0 & 0 & 0 \\
\hline Lepidoptera (larvae) & 1 & 2 & 2 & 6 & 0 & 1 & 0 & 1 & 0 & 0 \\
\hline Lepidoptera (adult) & 0 & 0 & 1 & 0 & 0 & 0 & 0 & 0 & 0 & 0 \\
\hline Thysanoptera & 0 & 0 & 0 & 0 & 0 & 0 & 0 & 0 & 1 & 0 \\
\hline Oligochaeta & 0 & 1 & 0 & 0 & 0 & 0 & 0 & 0 & 0 & 0 \\
\hline Pseudoscorpionida & 0 & 0 & 0 & 0 & 0 & 0 & 0 & 0 & 1 & 0 \\
\hline
\end{tabular}

Trapping locations: RP = Reef Point, $\mathrm{AB}=$ Anchorage Bay, NP = North Plains crater (all summer 2011), HC = Hut Creek (autumn 2016) 
were identified from one stomach (M173). Oligochaeta, Coleoptera larvae, adult Lepidoptera, Pseudoscorpionida and Thysanoptera were also identified.

Mice stomach contents analysis suggested that Orders such as Diptera larvae were being opportunistically consumed (low incidence prey items but consumed in high proportions when encountered) while others such as Araneae, Coleoptera adults and Lepidoptera larvae were regularly consumed staple diet items (all high incidence prey items) (Fig. 3). Mice were differentially targeting some Orders of invertebrates relative to their abundance in pitfall traps on the main Antipodes Island. In both summer 2011 and winter 2016, Lepidoptera were preferentially targeted by over 200-fold and Oligochaeta over 20-fold, while Coleoptera at only $0.26-0.39$ of their relative abundance.

Stable isotopes

A total of 398 samples for stable isotope analysis were obtained from across the main Antipodes Island (Table 3). Unfortunately, some key taxa (e.g. adult Lepidoptera) were not available from either pitfall traps for which they are not susceptible or mouse stomachs most likely because they are scarce in the ecosystem as a preferred diet item of mice.

The isotopic niches of terrestrial sources were tightly circumscribed and overlapping (Fig. 4). Isotopic niches differed little between years except in $\delta^{15} \mathrm{~N}$ values where land bird nitrogen isotope values increased in winter $(p=0.01)$, while mice decreased in winter $(p<0.01)$. Results from the SIMMR mixing model indicated that mouse diets varied between seasons, being dominated by invertebrates and land birds in summer 2011 (63\% of diet), with a greater reliance on plants and seabirds in winter 2013 (72\% of diet) (Table 4, Fig. 5). Marine macroalgae are also likely to increase in importance during the winter. However, as a result of isotopic overlap among sources (Fig. 4), model outputs struggled to resolve estimates between some potential sources, and this issue is reflected in the wide credible intervals for land bird consumption in summer 2011 (high negative correlation with land invertebrates, - 0.94) and seabirds in 2013 (strong negative correlations with both land plants, -0.80 , and marine macroalgae, $-0.75)$.
Fig. 3 Incidence versus proportion of invertebrates per order of food items in 20 mouse stomachs from Antipodes Island

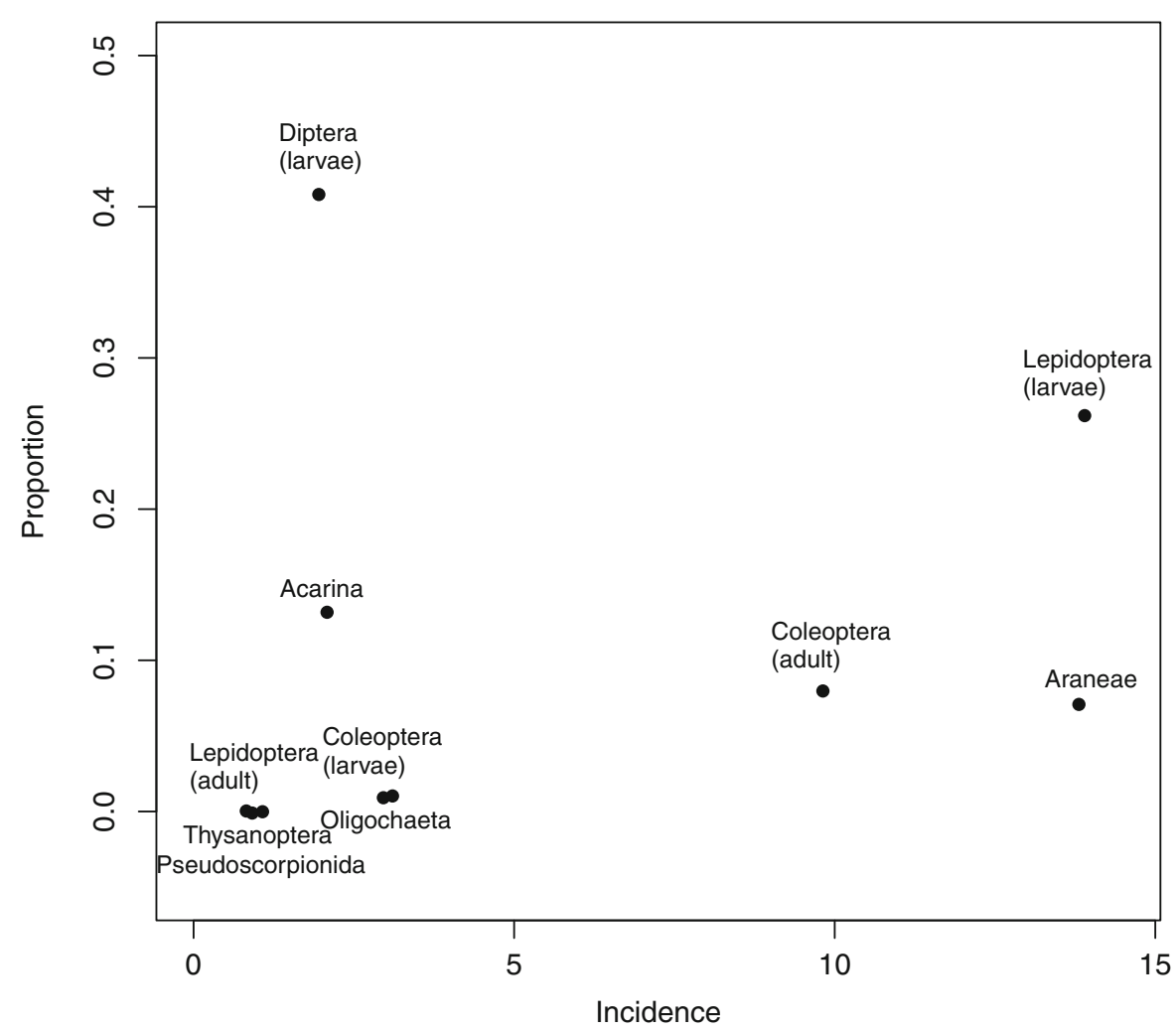


Table 3 Samples for table isotope analysis collected on Antipodes Island in summer (January) 2011 and winter (July) 2013
Mean (SD) are given for each taxonomic group

\section{Discussion}

The majority of food items identified in stomachs were invertebrate fragments, consistent with global findings

\begin{tabular}{|c|c|c|c|c|c|}
\hline Organism & Tissue & 2011 & 2013 & $\delta^{15} \mathrm{~N}$ & $\delta^{13} \mathrm{C}$ \\
\hline Land mammals & & & & $15.37(3.10)$ & $-23.76(4.08)$ \\
\hline Mice & Liver & 63 & 64 & & \\
\hline Land birds & & & & $12.17(4.39)$ & $-21.08(3.23)$ \\
\hline Antipodes parakeet & Blood & 5 & 5 & & \\
\hline Reischeks parakeet & Blood & 5 & 5 & & \\
\hline Antipodes snipe & Blood & 5 & 5 & & \\
\hline Antipodes pipit & Blood & 5 & 5 & & \\
\hline Seabirds & & & & $11.89(4.20)$ & $-21.15(2.99)$ \\
\hline White-headed petrel & Blood & 5 & - & & \\
\hline White-chinned petrel & Blood & 5 & 1 & & \\
\hline Grey-backed storm petrel & Blood & 5 & 1 & & \\
\hline Light-mantled sooty albatross & Blood & 2 & - & & \\
\hline Erect crested penguin & Feather & 5 & - & & \\
\hline Rock hopper penguin & Feather & 4 & - & & \\
\hline Soft-plumaged petrel & Blood & 5 & - & & \\
\hline Fairy prion & Blood & 5 & - & & \\
\hline Northern giant petrel & Blood & 5 & - & & \\
\hline Subantarctic skua & Blood & 3 & - & & \\
\hline Antipodean albatross & Blood & 5 & 5 & & \\
\hline Grey petrel & Blood & 1 & 5 & & \\
\hline Land invertebrates & & & & $14.15(3.92)$ & $-22.45(4.39)$ \\
\hline Coleoptera & Body & 5 & 4 & & \\
\hline Isopoda & Body & 6 & 5 & & \\
\hline Araneae & Body & 5 & 4 & & \\
\hline Diptera & Body & 5 & 4 & & \\
\hline Gastropoda & Body (no shell) & 2 & 1 & & \\
\hline Marine invertebrates & & & & $13.83(4.10)$ & $-22.36(4.59)$ \\
\hline Cellana strigilis & Body (no shell) & 4 & 5 & & \\
\hline Land plants & & & & $13.73(4.25)$ & $-23.64(4.60)$ \\
\hline Anisotome antipoda & Seed/Foliage & 7 & 7 & & \\
\hline Poa litorosa & Seed/Foliage & 7 & 7 & & \\
\hline Carex trifida & Seed/Foliage & 5 & 6 & & \\
\hline Leptinella plumosa & Foliage & 5 & 5 & & \\
\hline Crassula moschata & Foliage & 4 & 4 & & \\
\hline Urtica australis & Seed/Foliage & 5 & 4 & & \\
\hline Carex appresa & Seed/Foliage & 5 & 5 & & \\
\hline Coprosma perpusilla & Fruit/Foliage & 6 & 6 & & \\
\hline Coprosma ciliata & Foliage & 5 & 4 & & \\
\hline Marine macroalgae & & & & $13.48(4.20)$ & $-23.09(4.73)$ \\
\hline Durvillaea antarctica & Foliage & 5 & 5 & & \\
\hline Gigartina pachymenioides & Foliage & 5 & 5 & & \\
\hline
\end{tabular}

that at high latitudes mouse diet is dominated by invertebrates (St Clair 2011). Pitfall trapping of invertebrates showed a severe reduction in abundance, but not in diversity, attributable to mice on the main 


\section{Summer 2011}

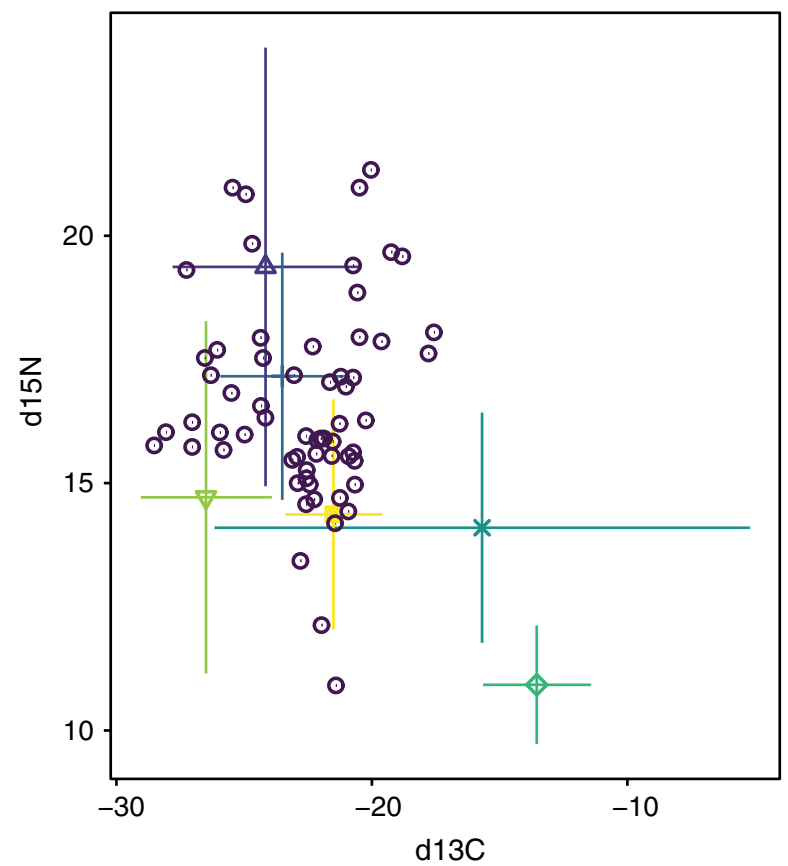

Winter 2013

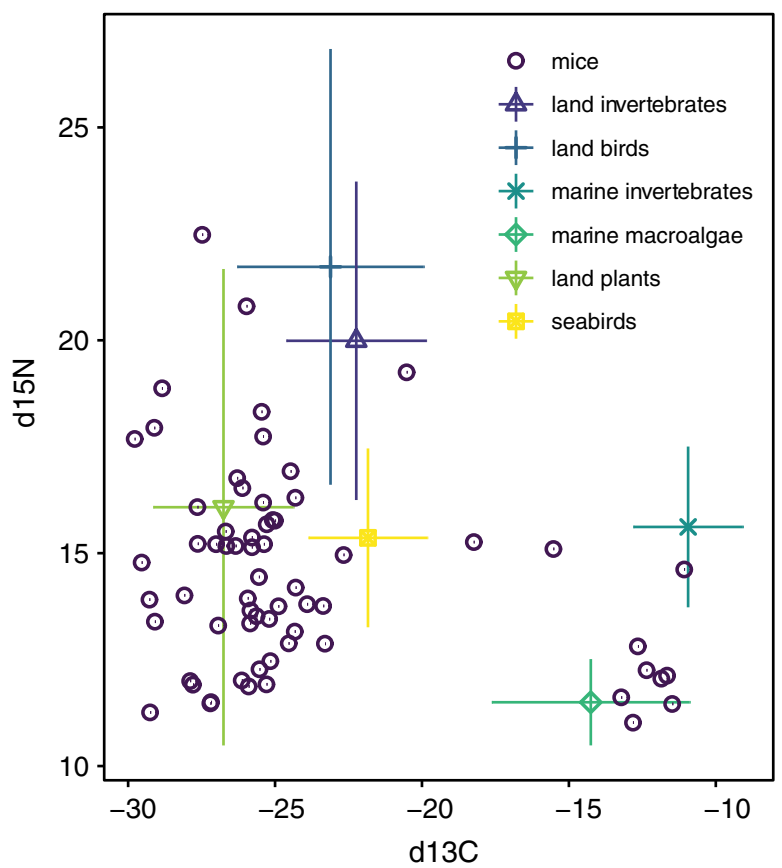

Fig. $4 \delta^{15} \mathrm{~N}$ and $\delta^{13} \mathrm{C}$ values of mice on Antipodes Island in summer (January) 2011 and winter (July) 2013. Resources are shown as mean $\pm \mathrm{SD}$

Table 4 Dietary proportions of mice on Antipodes Island in summer (January) 2011 and winter (July) 2013 estimated from SIMMR mixing model

\begin{tabular}{llllll}
\hline Year & \multicolumn{2}{l}{2011 (summer) } & & \multicolumn{2}{c}{2013 (winter) } \\
\cline { 2 - 3 } Source & Mean & SD & & Mean & SD \\
\hline Land birds & 0.354 & 0.243 & & 0.032 & 0.027 \\
Seabirds & 0.115 & 0.087 & & 0.287 & 0.150 \\
Land invertebrates & 0.274 & 0.144 & & 0.038 & 0.027 \\
Marine invertebrates & 0.081 & 0.047 & & 0.033 & 0.022 \\
Land plants & 0.119 & 0.074 & & 0.437 & 0.088 \\
Marine macroalgae & 0.057 & 0.032 & & 0.172 & 0.078 \\
\hline
\end{tabular}

Antipodes Island compared to mouse-free offshore islands. This difference was driven by certain taxa, which are presumably differentially preyed upon. Amphipoda, in particular, dominated pitfall traps on mouse-free offshore islands, but were virtually absent on the mouse-invaded main island. Comparison of mouse stomach contents to prey availability suggested ongoing prey preference by mice for some remaining taxa on Antipodes Island. In particular, we found Lepidoptera larvae to be a relatively common component of stomach contents, as found on other subantarctic islands (Copson 1986; Crafford and Scholtz 1987; Rowe-Rowe et al. 1989; Le Roux et al. 2002; Smith et al. 2002). Such strong preference for certain prey items suggests that mice are systematically consuming their way through the terrestrial ecosystem by exhausting preferred prey and then moving on to the next preferred prey source. The end point of this may be similar to that observed on other subantarctic islands where diet shifting from lower trophic levels to large seabirds eventually occurs (Cuthbert et al. 2013, 2014; Dilley et al. 2018; McClelland et al. 2018). This is potentially an outcome of mice, having been present for much longer on those islands, exhausting all other available food resources.

Mice have previously been invoked as the driver for a cessation in snipe (Coenocorypha aucklandica meinertzhagenae) breeding activity over summer, through an unknown mechanism that is only observed on Antipodes Island (Miskelly et al. 2006). Our results found that over summer land birds do indeed feed significantly lower in the food chain, putatively an outcome of competition with mice for invertebrates, 
Fig. 5 Comparison among estimated proportions of mouse diet on Antipodes Island in summer (January) 2011 and winter (July) 2013 using SIMMR source apportionment model. Boxes comprise 25-75\% credible intervals and whiskers illustrate $95 \%$ credible intervals

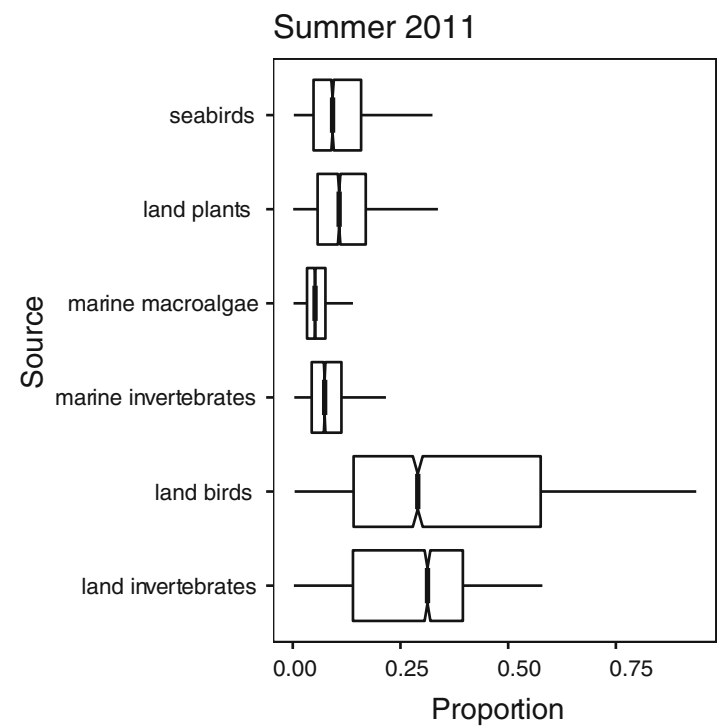

Winter 2013

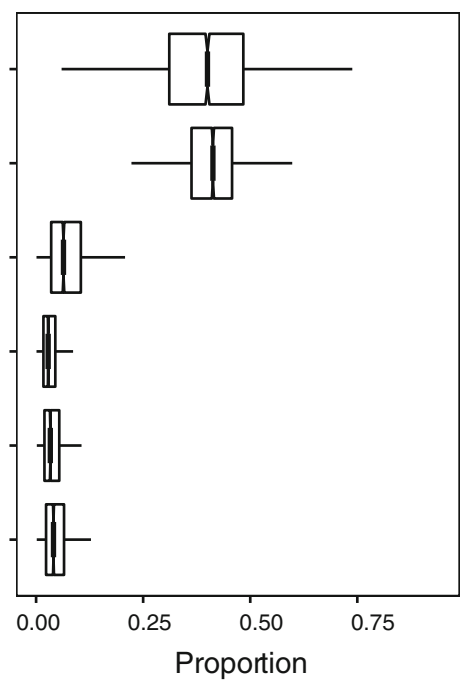

which may prevent snipe reaching adequate breeding condition. Furthermore, mice may also prey upon land birds over summer. This suggests that mice do indeed have a strong impact on snipe through exploitation competition, and potentially also predation. Early monitoring of terrestrial ecosystem recovery following the eradication of mice on Antipodes Island has already reported a fivefold increase in snipe detection (Cox 2018).

While feathers were found in a high proportion of mouse stomachs, scavenging is considered the most likely source of vertebrate material in the mouse diet. The two stomachs from the Anchorage Bay penguin colony contained feathers, Dipteran larvae, and Acarina of a size consistent with being ecto-parasites of a large bird, suggesting that a rotting bird carcass was scavenged with the ecto-parasites and maggots also consumed. Mice are adept scavengers and consuming a bird carcass would also result in feathers being ingested (e.g. Smith et al. 2002). Bird carcasses on Antipodes Island are cleaned to the bone in a matter of days (JCR pers. obs.). However, we cannot rule out predation, particularly on nestlings of small land and sea birds, and mice on Antipodes Island have been hypothesised to prey upon storm petrels (Moors and Atkinson 1984; Angel et al. 2009). Regardless, both forms of consumption will alter the nutrient flow on Antipodes Island (Drake et al. 2011).

Consumption of resources such as eggs and soft bird and invertebrate tissues would be difficult to detect via traditional stomach contents analysis, and stable isotopic mixing models do suggest that vertebrate consumption has the potential to be higher than recorded via traditional methods. However, the high negative correlation between land bird and land invertebrate sources in summer means that estimated proportions consumed for these two sources are poorly resolved (Parnell et al. 2013; Brett 2014). Thus, combining information from both methods suggests that land invertebrates are the key resource for mice on Antipodes Island, and that while land birds are also likely to be consumed, the proportion may well be lower than the mean credible interval suggests. Similarly, mixing models also struggled to resolve dietary proportions between the three most highly consumed sources in winter. The isotopic niches of taxonomic groups living in the terrestrial ecosystem of Antipodes Island were heavily overlapping, reflecting the limited resource base found on the isolated island group, with notable subsidy by marine resources (Anderson and Polis 1998). Such overlap can be problematic when trying to resolve consumer diet source using stable isotopes and can bias towards generalist solutions (Brett 2014). However, the patterns we found were qualitatively consistent between stomach contents and stable isotopes, and similar seasonal shifts have been found on other subantarctic islands (e.g. Le Roux et al. 2002; Smith et al. 2002).

To determine the impacts of mice on Antipodes Island we made a number of assumptions. In 
particular, we assumed that any differences in invertebrate diversity between mouse invaded and uninvaded islands were only attributable to mice, and not other variables which we blocked for within our study design (e.g. season and habitat) and that our pitfall traps randomly sampled the landscape and available prey items. Although pitfall traps can be biased in the types of invertebrates they capture, they are likely a good characterisation of medium and large sized surface macroinvertebrates, which would be the preferred prey of mice (Chown and Smith 1993). Our sample size for stomach contents was also necessarily small as it had to make use of available material collected pre-eradication. However, Le Roux et al. (2002) found that analysing five to nine mouse stomachs from Guillou Island represented $90 \%$ of the principal contents of the 212 stomachs collected. Our comparison between seasons is problematically confounded by year. However, annual climate cycles on islands in the Southern Ocean are strong and consistent, compared to tropical islands (Russell and Holmes 2015), and inferred temperature records (Leihy et al. 2018) showed that neither 2011 nor 2013 were anomalous years.

Based on our study, we would expect to see substantial increases in the abundance of snipe, and invertebrate Orders including Amphipoda and Lepidoptera, following eradication of mice. Additional complex changes will also occur within taxa (e.g. Samaniego-Herrera et al. 2017). For example, preferred Coleoptera species (e.g. three specimens of the rare endemic Antipodes Islands weevil sub-species Gromilus insularis antipodarum were found in one stomach) have been extirpated or severely reduced on the main Antipodes Island. However, those Coleoptera species that remain are now a less preferred prey item (e.g. the abundant Stenomalium n.sp.). This leads to the counter-intuitive result of Coleoptera as a group being less abundant on the main Antipodes Island, while at the same time no longer being a preferred prey item due to species composition. Furthermore, feedbacks among taxa may alter recoveries e.g. invertebrate recovery may be dampened if land birds recovering from predation exert top-down limitation upon them (Sinclair et al. 2005).

Our study suggested broad predatory and some competitive impacts of mice across the terrestrial ecosystem. These impacts varied with seasons, tracking resource availability from abundant invertebrates and land birds over summer to terrestrial vegetation and seabirds in winter. Combining multiple methodological approaches to examine the diet of this invasive species has allowed us to robustly estimate these effects. Stable isotopes have been proposed as a tool to rapidly detect ecosystem recovery following invasive rodent eradication (Nigro et al. 2017). However, due to the limited and isotopically similar prey base on Antipodes Island, this method would struggle to capture changes in native consumers if used in isolation. Changes in native avian species following eradication are more likely to be numerical in response to increased prey abundance, rather than being reflected in substantial changes in niche breadth or prey type, unless functional responses also change with prey abundance. By combining stable isotopes with classical stomach contents analysis and prey availability comparisons between mouse-invaded and uninvaded islands, we were able to reliably demonstrate that systematic invertebrate prey preference by invasive mice on the main Antipodes Island was occurring. This was directly impacting some invertebrate Orders and indirectly impacting competing avian consumers on the island. These wide-ranging impacts further suggest that eradication of mice from Antipodes Island will release native species from both competitive and predatory effects, with consequent changes to nutrient flow in this isolated ecosystem.

Acknowledgements For assistance collecting samples in the field the authors thank David Thompson, Erica Sommer, David Boyle and Mark Fraser in summer 2011, Helen Nathan, Terry Greene and Graeme Elliott in winter 2013, Fin Cox in autumn 2016 and Jose Luis Herrera in winter 2016. Thanks to the Department of Conservation, Murihiku, for logistical support, and Hank Haazen and crew of the Tiama for transport. Funding was provided for the summer 2011 expedition by NIWA and winter 2013 expedition by the National Geographic Society (Grant No. 9322-13). Thanks to Stephen Thorpe, Robert Hoare, and John Marris for taxonomic identification of invertebrate samples. Thanks to Surrya Khanam for laboratory sorting, Julie Brown and Anna Kilimnik for stable isotope laboratory analyses and Wendy Nelson for macroalgae identification. JCR is currently funded by the Royal Society of New Zealand Rutherford Discovery Fellowship (Grant No. RDFUOA1404). TWB is currently funded by the European Union's Horizon 2020 research and innovation programme Marie Skłodowska-Curie Fellowship (Grant No. 747120). Thanks to Katherine Russell and two anonymous reviewers for feedback on the manuscript. This research was conducted under DOC entry (SO-29716-LND 1011/35) and research (SO29140-FAU 1011/20) permits, and University of Auckland Animal Ethics Committee approval (R845). 
Open Access This article is licensed under a Creative Commons Attribution 4.0 International License, which permits use, sharing, adaptation, distribution and reproduction in any medium or format, as long as you give appropriate credit to the original author(s) and the source, provide a link to the Creative Commons licence, and indicate if changes were made. The images or other third party material in this article are included in the article's Creative Commons licence, unless indicated otherwise in a credit line to the material. If material is not included in the article's Creative Commons licence and your intended use is not permitted by statutory regulation or exceeds the permitted use, you will need to obtain permission directly from the copyright holder. To view a copy of this licence, visit http://creativecommons.org/licenses/by/4.0/.

\section{References}

Anderson WB, Polis GA (1998) Marine subsidies of island communities in the Gulf of California: evidence from stable carbon and nitrogen isotopes. Oikos 81:75-80

Angel A, Wanless RM, Cooper J (2009) Review of impacts of the introduced house mouse on islands in the Southern Ocean: are mice equivalent to rats? Biol Invasions 11:1743-1754

Arneson LS, MacAvoy SE (2005) Carbon, nitrogen, and sulfur diet-tissue discrimination in mouse tissues. Can $\mathrm{J}$ Zool 83:989-995

Barrow LM, Bjorndal KA, Reich KJ (2008) Effects of preservation method on stable carbon and nitrogen isotope values. Physiol Biochem Zool 81:688-693

Bolton M, Stanbury A, Baylis AMM, Cuthbert R (2014) Impact of introduced house mice (Mus musculus) on burrowing seabirds on Steeple Jason and Grand Jason Islands, Falklands, South Atlantic. Pol Biol 37:1659-1668

Brett MT (2014) Resource polygon geometry predicts Bayesian stable isotope mixing model bias. Mar Ecol Prog Ser 514:1-12

Bugoni L, McGill RA, Furness RW (2008) Effects of preservation methods on stable isotope signatures in bird tissues. Rapid Commun Mass Spectrom 22:2457-2462

Chown SL, Smith VR (1993) Climate change and the short-term impact of feral house mice at the sub-Antarctic Prince Edward Islands. Oecologia 96:508-516

Copson GR (1986) The diet of the introduced rodents Mus musculus L. and Rattus rattus L. on subantarctic Macquarie Island. Aust Wildl Res 13:441-445

Cox FS (2018) Trip report-2018 monitoring, Antipodes Island mouse eradication. Department of Conservation internal report DOC-5479610

Crafford JE, Scholtz CH (1987) Quantitative differences between the insect faunas of sub-Antarctic Marion and Prince-Edward Islands: a result of human intervention. Biol Cons 40:255-262

Cuthbert RJ, Louw H, Parker G, Rexer-Huber K, Visser P (2013) Observations of mice predation on dark-mantled sooty albatross and Atlantic yellow-nosed albatross chicks at Gough Island. Antarct Sci 25:763-766
Cuthbert RJ, Cooper J, Ryan PG (2014) Population trends and breeding success of albatrosses and giant petrels at Gough Island in the face of at-sea and on-land threats. Antarct Sci 26:163-171

Cuthbert RJ, Wanless RM, Angel A, Burle M-H, Hilton GM, Louw H, Visser P, Wilson JW, Ryan PG (2016) Drivers of predatory behavior and extreme size in house mice Mus musculus on Gough Island. J Mammal 97:533-544

DeNiro MJ, Epstein S (1978) Influence of diet on the distribution of carbon isotopes in animals. Geochim Cosmochim Acta 42:495-506

DeNiro MJ, Epstein S (1981) Influence of diet on the distribution of nitrogen isotopes in animals. Geochim Cosmochim Acta 45:341-351

Dilley BJ, Schoombie S, Stevens K, Davies D, Perold V, Osborne A, Schoombie J, Brink CW, Carpenter-Kling T, Ryan PG (2018) Mouse predation affects breeding success of burrow-nesting petrels at sub-Antarctic Marion Island. Antarct Sci 30:93-104

Drake DR, Bodey T, Russell JC, Towns DR, Nogales M, Ruffino L (2011) Direct impacts of seabird predators on island biota other than seabirds. In: Mulder $\mathrm{CPH}$, Anderson WB, Towns DR, Bellingham PJ (eds) Seabird Islands: ecology, invasion, and restoration. Oxford University Press, New York, pp 91-132

Elliot GP, Greene TC, Nathan HW, Russell JC (2015) Winter bait uptake trials and related field work on Antipodes Island in preparation for mouse (Mus musculus) eradication. Department of Conservation, Wellington

Eriksson B, Eldridge DJ (2014) Surface destabilisation by the invasive burrowing engineer Mus musculus on a subAntarctic island. Geomorph 223:61-66

Fry B (2002) Stable isotopic indicators of habitat use by Mississippi River fish. J N Am Benthol Soc 21:676-685

Godley EJ (1989) The flora of Antipodes Island. NZ J Bot 27:531-563

Hogsden KL, McHugh PA (2017) Preservatives and sample preparation in stable isotope analysis of New Zealand freshwater invertebrates. NZ J Mar Freshwat Res 51:455-464

Horn S, Simmons B, Russell JC (2018) Antipodes island mouse eradication. In: Veitch CR, Clout MN, Martin AR, Russell JC, West CJ (eds) Island Invasives: scaling up to meet the challenge. IUCN, Gland

Huyser O, Ryan PG, Cooper J (2000) Changes in population size, habitat use and breeding biology of lesser sheathbills (Chionis minor) at Marion Island: impacts of cats, mice and climate change? Biol Cons 92:299-310

Kiszka J, Lesage V, Ridoux V (2014) Effect of ethanol preservation on stable carbon and nitrogen isotope values in cetacean epidermis: implication for using archived biopsy samples. Mar Mammals Sci 30:788-795

Le Roux V, Chapuis JL, Frenot Y, Vernon P (2002) Diet of the house mouse (Mus musculus) on Guillou Island, Kerguelen archipelago, Subantarctic. Pol Biol 25:49-57

Leihy RI, Duffy GA, Nortje E, Chown SL (2018) High resolution temperature data for ecological research and management on the Southern Ocean Islands. Sci Data 5:180177

Marris JWM (2000) The beetle (Coleoptera) fauna of the Antipodes Islands, with comments on the impact of mice; 
and an annotated checklist of the insect and arachnid fauna. J R Soc NZ 30:169-195

McClelland GT, Altwegg R, Van Aarde RJ, Ferreira S, Burger AE, Chown SL (2018) Climate change leads to increasing population density and impacts of a key island invader. Ecol Appl 28:212-224

McIntosh AR (2001) The impact of mice on the Antipodes Islands. In: McClelland P (ed) Antipodes Island expedition, October-November 1995. Department of Conservation, Invercargill, pp 52-57

Miskelly CM, Walker KJ, Elliot GP (2006) Breeding ecology of three subantarctic snipes (genus Coenocorypha). Notornis 53:361-374

Moors PJ, Atkinson IAE (1984) Predation on seabirds by introduced animals, and factors affecting its severity, vol 2. International Council for Bird Preservation Technical Publication, Pemberley, pp 667-690

Nigro KM, Hathaway SA, Wegmann AS, Millerter Kuile A, Fisher RN, Young HS (2017) Stable isotope analysis as an early monitoring tool for community scale effects of rat eradication. Rest Ecol 25:1015-1025

Parnell AC, Phillips DL, Bearhop S, Semmens BX, Ward EJ, Moore JW, Jackson AL, Grey J, Kelley DJ, Inger R (2013) Bayesian stable isotope mixing models. Environmetrics 24:387-399

Patrick B (1994) Antipodes Island Lepidoptera. J R Soc NZ 24:91-116

Renaud S, Rodrigues HG, Ledevin R, Pisanu B, Chapuis J-L, Hardouin EA (2015) Fast evolutionary response of house mice to anthropogenic disturbance on a Sub-Antarctic island. Biol J Linn Soc 114:513-526

Rowe-Rowe DT, Green B, Crafford JE (1989) Estimated impact of feral house mice on sub-Antarctic invertebrates at Marion Island. Pol Biol 9:457-460
Russell JC (2012) Spatio-temporal patterns of introduced mice and invertebrates on Antipodes Island. Pol Biol 35:1187-1195

Russell JC, Holmes ND (2015) Tropical island conservation: rat eradication for species recovery. Biol Conserv 185:1-7

Samaniego-Herrera A, Clout MN, Aguirre-Muñoz A, Russell JC (2017) Rodent eradications as ecosystem experiments: a case study from the Mexican tropics. Biol Invasions 19:1761-1779

Sinclair L, McCartney J, Godfrey J, Pledger S, Wakelin M, Sherley G (2005) How did invertebrates respond to eradication of rats from Kapiti Island, New Zealand? NZ J Zool 32:293-315

Smith VR, Avenant NL, Chown SL (2002) The diet and impact of house mice on a sub-Antarctic island. Pol Biol 25:703-715

St Clair JJH (2011) The impacts of invasive rodents on island invertebrates. Biol Cons 144:68-81

Taylor R (2006) Straight through from London. Heritage Expeditions, Christchurch

Veale AJ, Russell JC, King CM (2018) The genomic ancestry, landscape genetics and invasion history of introduced mice in New Zealand. R Soc Open Sci 5:170879

Warham J, Johns PM (1975) University of Canterbury Antipodes Island expedition 1969. J R Soc NZ 5:103-131

Publisher's Note Springer Nature remains neutral with regard to jurisdictional claims in published maps and institutional affiliations. 